\title{
EROTISMO EN EL TEATRO DE ROJAS ZORRILLA. I. LA RISA ERÓTICA*
}

\author{
Juan Matas Caballero \\ UNIVERSIDAD DE LEÓN
}

El tema erótico, y más concretamente la literatura erótica, habida cuenta de las circunstancias de la época (estrictas convenciones morales, religiosas, políticas; la censura y, lo que es peor, la autocensura; máxime, tratándose de piezas teatrales que sufrían una vigilancia más estrecha), ${ }^{1}$ tenía grandes dificultades para expresarse. De ahí que la inmensa mayoría de los textos que pueden considerarse eróticos se difundieran de forma anónima o, en todo

\footnotetext{
* Este trabajo se ha realizado en el marco del proyecto de investigación del Plan Nacional I+D «Edición de la obra dramática de Rojas Zorrilla: IV. Comedias en colaboración con Vélez y otros autores» (HUM2005-07408-C04-04), financiado por el Ministerio de Educación y Ciencia y los Fondos Feder, y del proyecto de investigación «La comedia en colaboración del Siglo de Oro» (UXXI2007/0096), financiado por la Consejería de Educación de la Junta de Castilla y León.

${ }^{1}$ Los moralistas y erasmistas en el Siglo de Oro condenaron la lascivia e insania en la literatura, como, por ejemplo, hicieron con los libros de caballerías, donde era frecuente la realización física del amor. Véase A. Castro, El pensamiento de Cervantes, ed. J. Rodríguez Puértolas, Barcelona, Noguer, 1972, pp. 60-61, y M. Bataillon, Erasmo y España, Buenos Aires, FCE, 1966², p. 615.
} 
caso, apócrifa; única manera, tal vez, de poder burlar o franquear las rígidas estructuras represoras de la época.

El problema de la expresión o difusión de textos de naturaleza erótica se hacía, sin duda, mucho más complicado si tales obras pretendían publicarse, o representarse, bajo una rúbrica o firma real o verdadera. Tales dificultades, en cualquier caso, no impidieron la difusión de textos susceptibles de ser considerados eróticos o que incluyeran dicho tema. ${ }^{2}$ Así, la literatura del Siglo de Oro nos ofrece un amplio muestrario -más del que, a priori, podría sospecharse- de textos eróticos o, en su caso, con tal contenido, no necesariamente reducidos al ámbito de la anonimia.

Ahora bien, cuando nos internamos en el amplio campo de la literatura áurea, para entendernos, culta y, por lo tanto, de autoría pública o reconocida, el problema de hallar testimonios de naturaleza erótica es más difícil, precisamente porque la censura, y sobre todo, la autocensura, actuaba de manera hartamente operativa hasta el punto de laminar todo resquicio de licencias. Sin embargo, ni siquiera tal actividad policial consiguió, con todo, acabar con la presencia de textos, si no del todo eróticos, con contenidos, alusiones, referencias de naturaleza sensual. Ahora bien, ¿cómo consiguieron los autores introducir tales contenidos en sus obras? Cabe pensar que el camino para tratar lo erótico era, a menudo, un camino oblicuo, de manera que el escritor utilizaba toda suerte de recursos y procedimientos que le permitieran vadear los límites y dificultades que imponía la censura.

No fueron pocos los procedimientos esgrimidos para la expresión del erotismo. Sin duda, lo más común fue la asimilación a la ideología del poder represor, de manera que, a través de la censura de lo erótico o lascivo, el poeta de alguna forma también exponía la materia censurable. La sátira o crítica de lo erótico podía permitir de algún modo la presencia de tales elementos sensuales, aunque fuera para condenarlos. En este sentido, encontraríamos la sátira de tipos o estados, tan frecuente en el Siglo de Oro, donde se censuraba o criticaba,

\footnotetext{
${ }^{2}$ Se baraja el concepto de literatura erótica como aquella que en el Siglo de Oro expresa lo amatorio o sensual y la tendencia a la consumación amorosa. Al mismo tiempo, el concepto de erotismo se reduce, de acuerdo con Bataille, a la actividad sexual del hombre «cuando no es rudimentaria, cuando no es simplemente animal»; La felicidad, el erotismo y la literatura. Ensayos 1944-1961, Selección, traducción y prólogo de Silvio Mattoni, Buenos Aires, Adriana Hidalgo, 2001 (1988), p. 339. Díez Fernández nos ha ofrecido recientemente una excelente visión de conjunto del erotismo en la poesía áurea: La poesía erótica de los Siglos de Oro, Madrid, Ediciones del Laberinto, Arcadia de las Letras, 2003; un trabajo que está aún pendiente en el ámbito del teatro del Siglo de Oro.
} 
con más o menos vehemencia, un amplio muestrario de tipos, comportamientos, actitudes, relacionados con la actividad sexual (la mujer lasciva, la viuda alegre, el cornudo, la prostituta o cortesana, la madre permisiva e interesada, etc.). Otro de los procedimientos era el recurso a la burla de tales tipos, conductas o actividades sexuales. Normalmente, esta burla, debido precisamente a la censura, solía ir de la mano de la sátira de lo erótico. ${ }^{3}$

Pero, sin duda, este corpus de obras de contenido erótico siempre utilizaba un amplio elenco de recursos expresivos para evitar la mención directa o la alusión o referencia clara a la materia sexual. No se trata de enumerar tales mecanismos que, al fin y al cabo, son los que el lenguaje figurado, la retórica, y la tradición léxica y literaria (culta y popular), proporcionaba al escritor. El concurso de todos estos procedimientos permitía, sin duda, la presencia de lo erótico - por supuesto, en sus muchas vertientes de lo verde, picaril o picante- en las obras de las grandes figuras de nuestra literatura áurea -Cervantes, Góngora, Lope, Quevedo-, y, conforme al centenario que celebramos hoy, Rojas Zorrilla.

A raíz de estas características, lo que parece evidente es que en estos autores cultos es muy difícil, por no decir imposible, encontrar obras enteras en las que se celebre lo erótico, en las que el tema del amor carnal o sexual sea tratado o cantado por su interés en sí mismo. Las circunstancias coyunturales de su tiempo lo hacían prácticamente imposible. Por eso, lo normal es que la materia erótica aparezca en tales obras (Quijote, Polifemo, Píramo y Tisbe, etc.) o autores de forma fragmentaria o parcial, es decir, prácticamente siempre dependiente de otros fines estéticos o ideológicos superiores (la condena moral, en el caso de Quevedo; la recreación «costumbrista», en el de Lope; la reivindicación de la libertad e igualdad de la mujer respecto de los hombres, en Cervantes; la crítica de la corte, en Góngora; la recreación mitológica, en todos; etc.). Pero esta evidencia no debería impedir el reconocimiento de lo erótico en la obra de nuestros grandes escritores del Siglo de Oro.

Tal es el caso de Francisco de Rojas Zorrilla, un dramaturgo en cuya obra el tema del amor carnal adquiere una gran importancia por diferentes razones: por la frecuencia y riqueza con la que lo trata en cualquiera de sus manifestaciones; por la variedad de motivos y tonos que presenta; por la diversidad de funciones

\footnotetext{
${ }^{3}$ A. Redondo había señalado cómo por la prohibición de lo erótico, cuando este tema aparece en la literatura lo hace sobre todo de forma burlesca, «y valiéndose a menudo de un vocabulario disémico, alusivo, heredero de la tradición cazurra»; «Las dos caras del erotismo en la primera parte del Quijote», Edad de Oro, IX (1990), p. 253.
} 
y significados que cumple. Una simple lectura de algunas de las obras de Rojas Zorrilla permitiría seleccionar una amplia galería de escenas, diálogos, parlamentos, en los que lo erótico adquiere un gran protagonismo, en cualquiera de sus expresiones, literaria o escénica. ${ }^{4}$ Es tal la cantidad de escenas donde está presente de alguna forma el erotismo en el teatro de Rojas Zorrilla que no resulta fácil su clasificación o sistematización para proceder, posteriormente, al estudio de su función y significado. No está en mi ánimo llevar a cabo esta labor clasificatoria de la materia erótica en el teatro de Rojas; ni siquiera pretender abarcarla en su totalidad, pues sería una tarea que necesitaría, cuando menos, una dedicación exclusiva en forma de monografía. Por los límites que imponen este tipo de trabajos, tan solo pretendo en esta ocasión acercarme tímidamente al estudio de un único aspecto del erotismo en el teatro de Rojas Zorrilla: la risa erótica o la unión del binomio conceptual erotismo y humor. ${ }^{5}$

\section{Tipos y prácticas del erotismo}

Tal vez una de las vertientes más ricas de la expresión de lo erótico en el teatro se dé a través del comentario jocoso, del chiste o la burla de los criados que, aunque no los únicos, son los que con más frecuencia y singularidad hacen gala de dicho repertorio. En el teatro de Rojas Zorrilla resulta muy frecuente la aparición de estas sales relacionadas con la sexualidad. Lo más recurrente es que tales bromas se pongan en boca del gracioso o criado, que es el elemento principal sobre el que recae la función cómica de la pieza. Los chistes de carácter erótico también cumplen, por lo tanto, un papel humorístico, que, sin embargo, no siempre será la única de sus funciones. ${ }^{6}$

\footnotetext{
${ }^{4}$ Cuando, como es el caso, hablamos de erotismo en el teatro áureo, no se puede obviar siquiera, aunque no sea aquí objeto de estudio, la referencia al erotismo escénico, pues, como afirmó J. Oleza: «El arte verbal del dramaturgo barroco es alambicado y oblicuo, proclive a las terceras intenciones, y deposita buena parte de su malicia más en la gestualidad de los actores que en la materialidad misma de la palabra»; «La comedia: el juego de la ficción y del amor», en Edad de Oro, X (1990), p. 206. En este sentido, no cabe duda de que el discurso teatral de Rojas Zorrilla ha sido uno de los que con más énfasis debió de alentar la representación escénica del erotismo.

${ }^{5}$ Por los aludidos problemas de espacio, dejo para otra ocasión una segunda parte de este estudio que se centra en lo que podemos llamar la otra cara de la vertiente erótica en la dramaturgia de Rojas Zorrilla: desnudo y violencia. Ni que decir tiene que la obra del toledano nos ofrece, desde luego, otros muchos temas y motivos eróticos susceptibles de ser estudiados, pero, a mi juicio, es esta paradójica doble cara del erotismo, humor y violencia, la que singulariza su tratamiento del tema.

${ }^{6} \mathrm{M}$. G. Profeti lo había señalado con estas palabras: «Sólo el ámbito bajo de la risa (las piezas cortas, la intervención del gracioso) puede acoger la alusión sexual, que se da - y esto es muy interesante-
} 
Las declaraciones de los criados son algo más que una simple parodia de las de los señores. El comienzo de las referencias a tópicos manidos del amor es desviado hacia expresiones más realistas, incluso eróticas, más acordes con su baja condición social. Si bien es cierto que - como señaló Profeti - queda prohibida «la mención directa al sexo»:

mientras se intensifica la alusión, a menudo de tipo dialógico, y muy transparente por cierto, tanto que [...] no se aludía para esconder la alusión sexual, sino para descubrirla de forma muy evidente, apelando al patrimonio de referencias en poder del espectador. Se trata, sin embargo, de una modalidad burlesca, baja, carnavalesca, más que erótica. ${ }^{7}$

La imagen degradada de la mujer suele ser fruto de la larga tradición misógina que se da en la literatura española y de la que participan casi de forma generalizada todos los poetas. Podría afirmarse, no obstante, que apenas si hay misoginia en el teatro de Rojas, donde la mujer normalmente sale muy bien parada. Las pocas notas que pueden ser susceptibles de ser consideradas misóginas caben situarlas en el ámbito de una misoginia genérica.

En Los áspides de Cleopatra, cuando Marco Antonio y Cleopatra han urdido la idea de huir juntos, el criado Caimán, a modo de ticoscopia, describe la diversión nocturna de Alejandría concretada en unas gentes que gozan en un prado. La descripción de Caimán parece una nueva relación de las prácticas eróticas de Alejandría, convertida en una especie de nueva Sodoma y Gomorra: ${ }^{8}$

En día tan singular tan común es la alegría, que anda suelta Alejandría y no hay quien la pueda atar. A cuanto se ve de aquí todo tu cuidado atienda; allí hay música y merienda, baile allí, juegos allí. que con rostro arrebolado sale a darse un colorado con el muchacho de quince. Ella hacer trampas intenta, que ha de engañarle recelo; ¡oiga, el diablo del mozuelo, qué bien juega a las setenta! Aquella dama avestruz

en el nivel comunicativo propio del teatro, el de la acción, que en el texto espectáculo se suma al de la palabra»; «La escena erótica de los siglos áureos», en M. Díaz-Diocaretz e I. M. Zavala (coors.), Discurso erótico y discurso transgresor en la cultura peninsular, Madrid, Ediciones Tuero, 1992, p. 71.

${ }^{7}$ Ibidem.

${ }^{8}$ Para las citas del teatro de Rojas Zorrilla sigo la edición de Mesonero Romanos, especificando al final, entre paréntesis, con número la página y con letra la columna correspondiente; Comedias escogidas de don Francisco de Rojas Zorrilla, Biblioteca de Autores Españoles, t. 54, Madrid, Atlas, 1952 (1861). En caso contrario, se indicará la edición empleada. 
No hay quietud que no retoce, aquel de ochenta, se pierde por salir a darse un verde con la muchacha de doce. Mira aquella vieja lince tres digiere y a uno ama; ¡Oh cuál será aquella dama, pues aquel mata la luz! ¡Qué pocos galanes nones olvida el amor cruel! (p. 433b)

La visión que cuenta Caimán parecería inspirada en los lugares de recreo de la corte madrileña. Todo comienza con una alusión a la relajación de los códigos morales («anda suelta»), que facilita la liberación de todos los deseos carnales, una lascivia que afecta a todo el mundo, sin respetar edades, sexo, ni condición. Como puede observarse, lo que podemos llamar las «metáforas cromáticas» que usa Caimán, que no son sino voces o expresiones características del lenguaje de germanías, sirven para aludir a las prácticas eróticas: un viejo «de ochenta» quiere salir a «darse un verde» ('relación sexual', 'excitarse una pareja acariciándose') ${ }^{9}$ con una «de doce». Caimán, en una imagen de gran plasticidad, se refiere a la vieja «con rostro arrebolado», por la pintura del afeite, ${ }^{10}$ que quiere «darse un colorado» ('azote', con claro sentido erótico) ${ }^{11}$ con uno «de quince». El criado también muestra a un mozuelo bien dotado para galantear eróticamente con las viejas: «qué bien juega a las setenta». Caimán nos muestra a la «dama avestruz», ${ }^{12}$ quien «tres digiere ${ }^{13}$ y a uno ama». Y también parece aludir a las relaciones eróticas de alguna dama que quiere preservar a toda costa su identidad; y a la promiscuidad del «amor cruel» que se olvida de «pocos galanes nones». Parece que la función de esta descripción sea la de enfatizar la idea de una Alejandría marco de los amores de Marco Antonio y Cleopatra-inmersa en un ambiente de desenfreno moral, en el que triunfa el amor erótico y lascivo, que puede explicar la pasión adúltera de los protagonistas.

La expresión de germanías darse un verde es utilizada de nuevo por Rojas en Abrir el ojo. Doña Hipólita responde a uno de los tipos que la sátira de

\footnotetext{
${ }^{9}$ C. Hernández y B. Sanz, Diccionario de Germanía, Madrid, Gredos, 2002, p. 491.

${ }^{10}$ El color arrebolado, es decir, 'rojo', se conseguía gracias a un conocido tipo de afeite llamado arrebol. Quevedo había usado el término en algunas ocasiones, como, por ejemplo, en su soneto Pinta el «Aquí fue Troya» de la hermosura: «tez que con pringue y arrebol semeja».

${ }^{11}$ C. Hernández y B. Sanz, Diccionario de Germanía, op. cit., p. 152.

${ }^{12} \mathrm{El}$ poeta se refiere, tal vez, a la voracidad erótica de dicha dama, que coincide en ese aspecto con el avestruz: «Come de todo cuanto le dan, o encuentra, sin tener diferencia ni gusto en uno más que en otro, y lo digiere con facilidad» (Autoridades).

${ }^{13} \mathrm{El}$ poeta parece usar digiere y ama con el mismo sentido de goce erótico, subrayando así la voracidad sexual de la «dama avestruz».
} 
estados dedicada a la mujer en el Siglo de Oro recogía con cierta frecuencia: la mujer hipócrita que llevaba una vida licenciosa, pero aparentaba honestidad y recato. ${ }^{14}$ Hipólita, que quiere que Don Clemente no se vaya, le dice algunas cosas no exentas de contenido erótico justificando que ella no es una dama vanidosa ni casquivana, y le insinúa que ella no es mujer que venda sus favores sexuales. También le aclara que: «nunca al sotillo / un verde me salgo a dar» (vv. 17-18). Era frecuente ir al sotillo a divertirse, pero la mención del «sotillo» ya estaba marcada en el Siglo de Oro como el ámbito para el solaz erótico. Basta recordar la letrilla de Góngora, que inspiró a otros autores, para afirmar el tipo de juegos eróticos que se practicaban en el sotillo:

No vayas, Gil, al Sotillo

que yo sé

quien novio al Sotillo fue,

que volvió después novillo. ${ }^{15}$

El carácter lascivo y libidinoso que adquieren los paseos en el sotillo viene remarcado, para colmo, con la expresión, ya comentada, «un verde me salgo a dar». Doña Hipólita se postula como buena para Don Clemente frente a las típicas mujeres de reconocida y abierta mala reputación, como las cortesanas, meretrices o prostitutas. De modo que ella se ofrece como mejor opción (vv. 68-80). La respuesta de Don Clemente trasluce su cansancio de la «mujer honrada», como la llama irónicamente (v. 157), pues la ha visitado (con un sentido claramente erótico) durante seis años (vv. 114-115). ${ }^{16}$ La ironía de Don Clemente deja al descubierto la verdadera naturaleza de Doña Hipólita, como se observa cuando ella le reprende por hablar alto: "“Repare que hay vecindad, / y aquí no es como las casas / donde no hay que reparar"» (vv. 134-136). También se evidencia la liviandad de costumbres de los dos, cuando Doña Hipólita alude en varias ocasiones al triángulo amoroso en el que viven: «Somos tres, no hay que espantar» (v. 152).

En Los áspides de Cleopatra, Caimán cuenta a Octaviano, Lépido e Irene, que, después de un año, han llegado a Alejandría en busca de Marco Antonio,

\footnotetext{
${ }^{14}$ Véase F. Pedraza y M. Rodríguez, «Introducción» y notas a F. de Rojas Zorrilla, Donde hay agravios no hay celos. Abrir el ojo, Madrid, Castalia, 2005, p. 258.

${ }^{15}$ L. de Góngora, Obras completas, I, ed. A. Carreira, Madrid, Fundación José Antonio de Castro, 2000, p. 538

${ }^{16}$ En la edición de P. Alzieu, R. Jammes e Y. Lissorgues, Poesía erótica del Siglo de Oro, Barcelona, Crítica, 2000², pp. 107-109, 173, 195 (en adelante, la citaré como PESO), puede verse varios testimonios de visitar con el sentido de futuere.
} 
cómo fueron recibidos sus soldados, insinuando ya lo que se avecinaba. Caimán había descrito el ejército de Marco Antonio como «cincuenta Cupidos», y el de Cleopatra como «suavísimas sirenas»; un término que en la época era sinónimo de 'prostituta': ${ }^{17}$

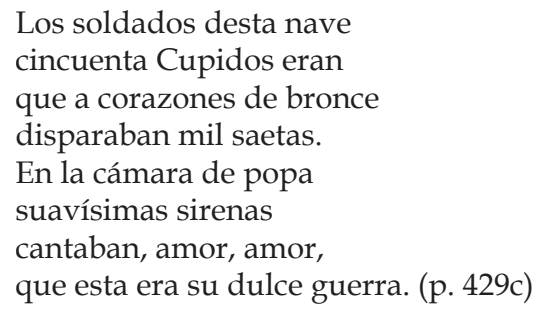

Pero, sin duda, tal vez sea Abrir el ojo la comedia de Rojas que más ejemplos ofrece de esta visión descarada y desvergonzada de las relaciones eróticas y, en particular, en relación con este epígrafe, de las mujeres de vida alegre, las cortesanas que venden sus favores sexuales. Pedraza y Rodríguez han señalado acertadamente la trascendencia en este aspecto de la comedia cínica por antonomasia de Rojas. ${ }^{18}$ Estas comedias cínicas presentan «un juego descarado de amores promiscuos y acomodaticios, de constantes contradicciones entre un lenguaje caballeresco y un comportamiento tan innoble como simpático y despreocupado, a ratos absurdo y siempre hilarante». «Su peculiaridad está en llevar más lejos, a terrenos socialmente más conflictivos, los alardes de libertad amorosa y de descaro que hay en estos precedentes». Estas piezas son un «fresco de la movida madrileña de 1640, pintado con desenfado, buen humor, cinismo y desvergüenza a raudales». ${ }^{19}$

Doña Clara es una mujer que responde muy bien al tipo de las cortesanas. Rojas hace una presentación magistral de la forma de ser y de actuar de Doña Clara, tomando como base las metáforas náuticas (que, curiosamente, tanto

\footnotetext{
${ }^{17}$ Como señaló J. Sepúlveda: «No puede sorprender esta contaminación semántica, puesto que las sirenas estaban relacionadas ya en la antigüedad con el reclamo sensual y engañoso. Por ello, alcanzaron una presencia significativa también en la lírica amorosa»; «Erotismo y mitología en la poesía satírico-burlesca de Quevedo», en I. Colón y J. Ponce (eds.), Estudios sobre tradición clásica y mitología en el Siglo de Oro, Madrid, Ediciones Clásicas, 2002, p. 41.

${ }^{18}$ F. Pedraza y M. Rodríguez, «Introducción» a F. de Rojas Zorrilla, Donde hay agravios no hay celos. Abrir el ojo, op. cit., pp. 23-24.

${ }^{19}$ Para obtener una visión completa del tono erótico de Abrir el ojo y, en particular, del tipo de la cortesana, véase la «Introducción» de F. Pedraza y M. Rodríguez a su citada edición.
} 
recorrido han tenido en la poesía de corte ético desde la antigüedad clásica hasta este tiempo), que Rojas ha empleado en varias ocasiones (vv. 532-575):20

\author{
De esta suerte: \\ Muchos son, amiga mía, \\ los piratas y cosarios \\ que en corso de mi belleza \\ surcan el golfo del Prado. \\ Apenas del puerto mío \\ las dos áncoras levanto \\ y la nao de mi hermosura \\ se pone vergas en alto, \\ cuando cercando mi coche, \\ que es mi nave, a un tiempo hallo \\ que hacen señal que me rinda \\ las naves de «Pie de Palo». \\ Las naves de España allí \\ disparan por el costado \\ versos que me dan asombro \\ y no me dan sobresalto. \\ Mas como saben que soy \\ nave zorrera, disparo \\ un pido, con que echo a fondo \\ a un tiempo todas las naos. \\ Y si algún navío rindo,
}

\author{
me le llevo remolcando \\ a la isla Confitería \\ en el golfo de Leplanto. \\ Si algún cosario perdido, \\ de aquellos que yo he robado, \\ se quiere abrigar conmigo, \\ de mi bandera le aparto; \\ que el grande golfo de Abido \\ solo es para los Leandros. \\ Si algún bergantín encuentro \\ de bergantes y taimados, \\ que a vela y remo procuran \\ darme caza, me adelanto \\ hacia la playa Viteli, \\ adonde al piloto lamo, \\ y digo: «¿Hay bajos aquí? \\ ¿Surgiré en este playazo?» \\ «Bajos hay -responden luego-, \\ pero como estos cosarios \\ no pueden sondar la playa, \\ peligran luego en los bajos». \\ Si llego...
}

En Peligrar en los remedios se observa cómo el criado Bofetón hace una descripción física de su señora y alude al vestido que lleva. En dicha referencia parece claro que el criado destaca cómo la dama se viste para llevar a cabo su ejercicio de seducción, al que se refiere a través de la tradicional metáfora de

\footnotetext{
${ }^{20}$ Los términos náuticos han sido con frecuencia usados para referirse al ámbito erótico; de hecho, la navegación de doña Clara no es sino la práctica del ejercicio de la prostitución; véase Alonso Hernández, El lenguaje de los maleantes españoles de los siglos XVI y XVII: la Germanía. (Introducción al léxico del marginalismo), Salamanca, Universidad, 1979, pp. 113, 114, 171; J. Sepúlveda, «"Caminar por do va el buey". Nota a La Lozana Andaluza, XI», en Orillas. Studi in onore di Giovanni Battista De Cesare, I, Il mondo iberico, ed. G. Grossi e A. Guarino, Salerno, Edizioni del Paguro, 2001, p. 349; y J. Ponce, «Sobre el epilio burlesco: aspectos léxicos y estrategias discursivas del erotismo en siete poetas barrocos», en Asimetrías genéricas. "Ojos ay que lagañas se enamoran". Literatura y género, ed. de E. Lacarra Lanz, Bilbao, Universidad del País Vasco, 2007, pp. 222-223; también la anotación de F. Pedraza y M. Rodríguez a F. de Rojas Zorrilla, op. cit., pp. 296-299.
} 
la caza, ${ }^{21}$ que, según la condición de su pieza, será mayor. En este contexto, resulta paradójico que la caza mayor se concrete en pajaritos ${ }^{22}$ y gallinas, ${ }^{23}$ con lo que estos términos adquieren, sin duda, una significación metafórica, distinta a su sentido recto, con un evidente valor erótico. De este modo, el poeta ha establecido una correspondencia entre el vestido de la dama y su finalidad a la hora de cazar a sus víctimas:

Para hacer caza mayor, redes por valona y vueltas, jaula para pajaritos, para gallinas pollera. $(352 b)$

En Los áspides de Cleopatra, Caimán también cuenta cómo las gentes se solidarizaban con los amores de Marco Antonio y Cleopatra, aludiendo a sus deseos eróticos, que no deja de ser una relación de tipos femeninos - la vieja, la viuda hipócrita, la soltera y la casada - vistos solo desde la perspectiva erótica. El eco de la sátira de estados resulta evidente, aunque en esta relación no hay, sin embargo, atisbo de crítica:

La casta anciana, que estuvo en su atención recoleta, sabiendo lo que ha perdido, no quisiera ser tan vieja. La viuda también buscaba un sustituto que lea en su cátedra del sexto del propietario la ausencia. En disolución tan libre, trocados los frenos vieras las solteras muy casadas,

\author{
corrieron en esta era, \\ que a más de cien mil Tarquinos \\ no se encontró una Lucrecia; \\ la tórtola enamorada, \\ la dulce paloma tierna, \\ por ser aves que amar saben, \\ las arrullan y gorjean; \\ la azucena y el jazmín, \\ símbolos de la pureza, \\ les daban humo a narices; \\ que solo del gusto eran
}

\footnotetext{
${ }^{21}$ A lo largo de la tradición literaria, la caza ha venido configurándose como una imagen tópica con la que realmente se significaba la caza de amor; una metáfora del deseo o acto sexual que fue muy empleada por Lope de Vega en su teatro; y, entre otros, también por Luis Vélez de Guevara.

${ }^{22}$ Aunque no en diminutivo, el pájaro ya había volado, con su valor metafórico como pene, en Catulo, de donde lo vimos posarse en la Fábula de Píramo y Tisbe de Góngora: «Ofrecióle su regazo / (y yo le ofrezco en su muslo / desplumadas las delicias / del pájaro de Catulo)» (vv. 449452); Obras completas, I, op. cit., p. 511. Como diminutivo, tal como lo usa Rojas Zorrilla, ha sido identificado con el miembro viril masculino en la tradición popular, en especial en el lenguaje infantil; véase J. Ponce, «Sobre el epilio burlesco: aspectos léxicos y estrategias discursivas del erotismo en siete poetas barrocos», op. cit., p. 201.

${ }^{23}$ El término gallinas puede referirse metafóricamente a los hombres 'cobardes o tímidos'.
} 
las casadas muy solteras.

Tan iguales voluntades la hiedra, por ser lasciva, por madre, la madre selva; (p. 430a)

Desde luego, el pasaje revela de forma tan evidente su sentido erótico que no necesita mayores comentarios. Caimán ha retratado toda una ciudad que celebra de forma concupiscente, en justa correspondencia, el amor de Marco Antonio y Cleopatra. Todas las alusiones también tienen una clara relación con la simbología erótica, y gozaban de una larga tradición en la literatura amatoria (el sexto, ${ }^{24}$ Tarquino y Lucrecia, ${ }^{25}$ la tórtola, la paloma, azucena y jazmín, hiedra, madreselva). ${ }^{26}$ Caimán cuenta cómo si la casta Cleopatra había promulgado una ley contra aquellos que se amasen, ahora la ha dictado contra los que no se amen.

Otro de los tipos relacionados con el ámbito erótico que aparece en algunas obras de Rojas es el cornudo. ${ }^{27}$ En Cada cual lo que le toca los criados hablan, murmuran, del matrimonio de sus señores (vv. 16 ss.). Hay insinuaciones de carácter erótico debido a lo que madruga su señor; la ruptura del sistema al transformar el conocido refrán — «A quien madruga Dios le ayuda» - en «Sí haze, pero más ayuda / a quien se queda en la cama» (vv. 11-12), parece sugerir que precisamente, su señor madruga porque quizá nada tiene que hacer en la cama. Las murmuraciones de los criados se remontan a la aciaga boda de sus amos, que se produjo en lunes, y, como señaló A. Castro: «Era vulgar la creencia de que el lunes ejercía acción nefasta (en forma varia) en los lances de amor». ${ }^{28}$ Los criados aventuran una explicación en sus murmuraciones:

\footnotetext{
${ }^{24} \mathrm{El}$ sexto alude al sexto mandamiento, es decir, «no cometerás actos impuros»; la viuda era catedrática en el sexto, es decir, experta en todos los actos carnales y buscaba un sustituto a su esposo fallecido. También en Góngora hallamos una décima, de 1607, en la que el poeta juega con los mandamientos: «que el amor que os he propuesto / no es hijo de Marte en esto, / antes de él es tan distinto, / que si me habláis en el quinto, / no os he de hablar en el sexto», Obras completas, I, op. cit., p. 250.

${ }^{25}$ La leyenda de Tarquino y Lucrecia, como paradigma de la violación, ha sido recreada o aludida por Rojas Zorrilla en diferentes ocasiones; véase, más adelante, la nota 36 de este mismo trabajo. ${ }^{26}$ La tórtola y la paloma también son aves relacionadas con el tema erótico: la paloma era un ave consagrada a Venus. La paloma ya había volado en la Fábula de Polifemo y Galatea como símbolo de la unión amorosa entre Acis y Galatea: «paloma se caló, cuyos gemidos» (v. 319). Con la mención de estas plantas trepadoras, de largo recorrido literario, el poeta alude a la unión sexual: jazmín y haya, hiedra y madreselva y muro, etc.

${ }^{27}$ Sobre el tema véase R. Cacho, La poesía burlesca de Quevedo y sus modelos italianos, Santiago de Compostela, Universidad de Santiago de Compostela, 2003, pp. 167-189.

${ }^{28}$ F. de Rojas Zorrilla, Cada cual lo que le toca y La viña de Nabot, ed. de A. Castro, en Teatro antiguo español. Textos y estudios. II, Madrid, Centro de Estudios Históricos, 1917, p. 201.
} 
ÁNGELA.

BELTRÁN.

ÁNGELA.

BELTRÁN.
Si por fuerza se casó

mi señora, ¿qué ha de hacer?

Si ella no es para mujer...

¡Bestia!

¿Pues digo mal yo?

Sabe, porque no te asombre, que hombre para mujer y la mujer para hombre.

Pero tú le oíste hablar palabras contra el honor

de mi amo y tu señor. (vv. 33-43)

La maldad de los criados parece sugerir dos posibilidades para los malogrados esposos: o la homosexualidad del señor o su condición de cornudo. $^{29}$

El criado Beltrán dice a don Fernando acerca de la infelicidad de Isabel con su esposo que ella no lo ama y que podría amar a otro. Un tanto ufano y estúpido, el propio Beltrán cree a pies juntillas el piropo que Isabel hizo sobre sus piernas: «Estimad / vuestras piernas, que no he visto / otras como ellas jamás» (vv. 15002), e incluso se estima capaz de ponerle los cuernos a su propio amo:

¿qué mucho que mi amo quiera

pegarme una estaca atrás, si echa de ver que también yo se la puedo pegar? (vv. 1507-10)

La estulticia de Beltrán llega al extremo de pensar que su amo lo dejaría entrar en el dormitorio de Isabel (vv. 1546-8).

La imagen del cornudo ha sido asociada de forma simbólica con uno de los signos zodiacales. Así, sin concretar en nadie, en Primero es la honra que el gusto, Pepino alude al tormentoso problema de la pareja a través de una tópica imagen al uso, como es la alusión al signo zodiacal de Capricornio: ${ }^{30}$

\footnotetext{
${ }^{29}$ Sobre el tema de la homosexualidad en el teatro de Rojas véase F. Pedraza, «Variantes del galanteo en Rojas Zorrilla», en Ronda, cortejo y galanteo en el teatro español del Siglo de Oro, ed. R. Castilla Pérez, Granada, Universidad de Granada, 2003, pp. 125-127.

${ }^{30} \mathrm{El}$ chiste era frecuente incluso en la literatura culta, como en Góngora quien lo recrea en $E l$ doctor Carlino cuando dice Casilda al Doctor: «¿De suerte, amigo, que dices / que al Capricornio galán / sacándole ahora están / de su brazo las narices?» (vv. 605-608); Teatro completo, ed. Laura Dolfi, Madrid, Cátedra, 1993, p. 266.
} 


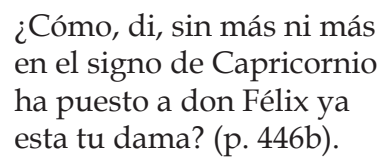

En Abrir el ojo también hallamos otro chiste de contenido sexual, cuando el criado Cartilla alude a la infidelidad de la dama y a cómo actuaría él en esa circunstancia:

CARTILLA.

Yo,

la que me pone dos huesos

en la frente sin dolor,

más abajo de la frente

la pongo cinco por dos. (vv. 1225-28)

En la Numancia cercada ${ }^{31}$ también hallamos otra alusión a los cuernos en el diálogo que mantienen los graciosos Olalla y Tronco. Si aquella ha insultado a Tronco al llamarlo «asno», diferenciando entre los «maridos cortesanos / y discretos» $\mathrm{y}$ «los hombres ingeridos / en asnos como sois vos», éste le responde:

$$
\begin{aligned}
& \text { Ya de vuestros pareceres } \\
& \text { sé que hay maridos tan malos } \\
& \text { que se dejan dar de palos, } \\
& \text { Olalla, de sus mujeres. (vv. 650-653) }
\end{aligned}
$$

En este caso, palos no se refiere a los 'golpes' que tales maridos reciben de sus mujeres, sino que tiene un significado erótico, pues con ese término alude a los actos sexuales, en este caso a los 'cuernos', es decir, palos que admite el cornudo consentido. ${ }^{32}$ Pero Tronco no se queda sólo en la teoría sino que él, que ha sido comparado con un asno (tradicionalmente, el animal ha sido asociado a la lujuria y virilidad), ${ }^{33}$ está dispuesto a golpearla, «os le tengo de quebrar / en las costillas» (vv. 656-657), a darle un palo, es decir, a llevar a la práctica los deseos e intenciones eróticas que Olalla le ha atribuido en su comparación.

\footnotetext{
${ }^{31}$ F. de Rojas Zorrilla, Numancia cercada y Numancia destruida, ed. R. R. MacCurdy, Madrid, José Porrúa Turanzas, 1977; agradezco a mi colega y amiga Gemma Gómez Rubio su generosidad al apuntarme y enviarme la escena de contenido erótico de esta pieza.

${ }^{32}$ Esta interpretación propuso también el editor de la obra; ibidem, p. 32.

${ }^{33}$ J. Sepúlveda, «"Caminar por do va el buey”. Nota a La Lozana Andaluza, XI», op. cit., p. 352.
} 
Uno de los motivos que Rojas Zorrilla recrea con demasiada frecuencia en su teatro es el de la violación o intento de violación ${ }^{34}$. Si tal frecuencia resulta un tanto sorprendente, más aún extraña que en semejantes trances aparezcan los criados haciendo chistes de un tema tan escabroso. En No hay ser padre siendo rey parece haber una alusión burlesca a la violación. Como los nombres de los criados suelen tener un significado ya de por sí gracioso, que alude a su simpleza intelectual (Bofetón, Zambapalo, Gibaja, etc.) y facilitan los juegos de palabras, ${ }^{35}$ en esta pieza el criado Coscorrón sabe las perversas intenciones del príncipe Rugero, pues, de hecho, ha sido él quien ha traicionado por dinero a su ama la Duquesa, de ahí que, cuando Rugero entra en la casa le dijera aludiendo a la proverbial violación de Tarquino: «y encomiéndate a Tarquino» (v. 1501). ${ }^{36}$ Su humor negro le permite hacer un chiste con su nombre, que identifica con el «Coscorrón que dio Rodrigo / a la Cava» (vv. 3017-18), con lo que se asocia el «coscorrón» con la «violación». ${ }^{37}$ Dentro de la general misoginia de la época, el gracioso generaliza que eso debe ser lo que hay que hacer con todas las mujeres hermosas:

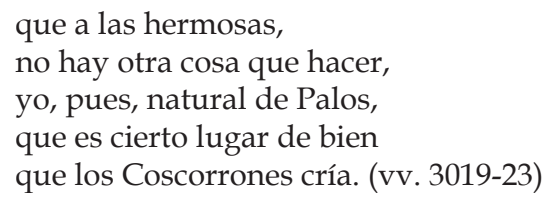

El chiste erótico cobra más fuerza aún cuando Coscorrón, usando el término palos - como hizo Rojas anteriormente - fija su origen natural en un lugar llamado Palos (¿Palos de la provincia de Murcia, o Palos de la Frontera,

\footnotetext{
${ }^{34}$ Véase mi trabajo «Erotismo en el teatro de Rojas Zorrilla. II. Desnudo y violencia», en Actas del Congreso Internacional sobre Francisco de Rojas Zorrilla, celebrado en Toledo, los días 4 al 7 de octubre de 2007 (en prensa).

${ }^{35}$ Véase, por ejemplo, F. de Rojas Zorrilla, Numancia cercada, op. cit., p. 79.

${ }^{36}$ Rojas Zorrilla estaba muy familiarizado con la legendaria violación de Tarquino, pues también dedicó una pieza a la trágica leyenda: Lucrecia y Tarquino. Aprovecho la cita para agradecer a mi buen amigo Rafael González Cañal su diligencia y generosidad al facilitarme copia de esta y otras obras de Rojas Zorrilla. Las citas de esta pieza se hacen por las Obras completas, I, Primera parte de comedias. No hay amigo para amigo. No hay ser padre siendo rey. Donde no hay agravios no hay celos. Casarse por vengarse, Edición crítica del Instituto Almagro de teatro clásico, dirigida por F. B. Pedraza Jiménez y R. González Cañal, y coordinada por E. E. Marcello, Cuenca, Universidad de Castilla-La Mancha, 2007.

${ }^{37}$ Alude a otro paradigma de la violación, la de don Rodrigo a la Cava; véase, más adelante, la nota 40 de este trabajo.
} 
de la de Huelva?), que tradicionalmente, en singular, no solo significa golpe, sino que se ha identificado con el órgano viril masculino. ${ }^{38}$

En Los bandos de Verona hallamos una nueva alusión a la tópica violación de Tarquino cuando el criado Guardainfante cuenta en forma de burla el intento de violación de Andrés sobre Julia:

Violencia quiso Andresillo,

dijo ella: «Andresillo, tente.»

Y él respondió: «Los Tarquinos

son chanza donde hay Andreses.» (p. 383b)

En la pieza Entre bobos anda el juego hallamos otra alusión de carácter misógino cuando don Lucas generaliza:

Mujer que se haya criado

en Toledo es lo que quiero,

$\mathrm{y}$ aunque naciese en mi barrio.

Mujer criada en Madrid,

para mí, propia, descarto,

que son de revés ${ }^{39}$ las unas,

y las otras son de Tajo. (p. 31ab)

La expresión «de Tajo» parece tener un valor bisémico, pues si unas damas son «de revés», es decir, 'de cuchilla', «las otras» son de 'tajada' (en relación con el corte o tajo); pero también parece tener una connotación erótica y aludir al mítico episodio de la violación de la Cava por don Rodrigo, concretado metonímicamente en el Tajo (p. 31b). ${ }^{40}$ No falta, de forma un tanto excepcional, el chiste grosero y vulgar entre los personajes de baja condición, en boca de los Caminantes y Cabellera (p. 31c).

\footnotetext{
${ }^{38}$ Véase PESO, op. cit., p 144.

${ }^{39}$ En lenguaje de germanías, revés significa 'cuchillada'; véase C. Hernández y B. Sanz, Diccionario de Germanía, op. cit., p. 421.

${ }^{40}$ Recuérdese la leyenda de don Rodrigo y la Cava, magistralmente poetizada por fray Luis de León, Poesía completa, ed. G. Serés, Madrid, Taurus, 1990, pp. 74-77; sobre el poema puede verse el interesante artículo de G. Haley, «La triple invasión: la "Profecía del Tajo", de fray Luis de León», Edad de Oro, IX (1990), pp. 93-112. J. I. Díez Fernández (La poesía erótica..., op. cit., p. 193) señaló cómo el desarrollo erótico del tema de don Rodrigo y la Cava lo ejemplifica, además, el poema de Pedro Méndez de Loyola «La fuerza de la Caba, glosada con diferentes romances». Véase Pedro del Corral, Crónica del rey don Rodrigo (Crónica Sarracina), ed. James Donald Foquelquist, Madrid, Castalia, 2 vols., 2001, I, pp. 448 ss.; sobre el tema véase la edición de P. Díaz Mas, Romancero, Barcelona, Crítica, 1994, pp. 134-136.
} 


\section{CAMPOS lÉXICOS Y LITERARIOS DE LA RISA ERÓTICA}

Como suele ser habitual en los poetas que han cultivado el tema erótico, Rojas Zorrilla desarrolla toda una serie de imágenes sexuales que se codifican a través de distintos campos semánticos (cuerpo, alimento, juego, etc.), motivos o tópicos literarios (militia amoris, imágenes ígneas), y el uso de procedimientos estilísticos (metáforas verbales, refranes, clichés o frases hechas). En líneas generales, se trata de un código sexual alusivo que es compartido por la literatura, culta y popular, de su tiempo, lo que no cabría entenderlo como falta de originalidad o de renovación del caudal erótico (pues sí ofrece algunos ejemplos que resultan novedosos), sino de eficacia comunicativa para garantizar que el significado o valor sexual de la expresión sea captado por el variado público.

En el promiscuo ambiente de Los áspides de Cleopatra resulta normal que, de alguna forma, el cuerpo sea el protagonista de los amores entre Marco Antonio y Cleopatra. Quizá por eso, vemos cómo Caimán en su relación cuenta en qué partes del cuerpo de Marco Antonio se detenía la mirada erótica de Cleopatra:

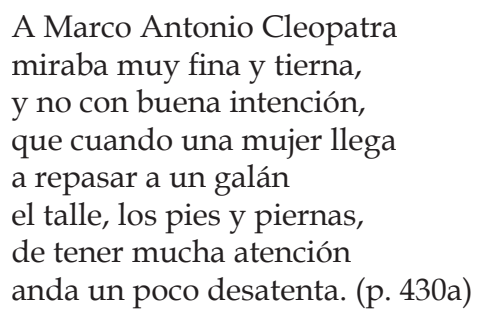

Desde luego, el repaso visual de Cleopatra era evidentemente erótico, pues, según cuenta Caimán, dirigía su mirada «no con buena intención» al cuerpo de Marco Antonio, concretamente al «talle, los pies y piernas», que en el Siglo de Oro tenían un evidente valor sexual. ${ }^{41}$ Cleopatra fijó sus ojos en los pies de Alejandro, de forma un tanto lasciva, pues era común la creencia de una relación entre las medidas del pie y las del sexo. ${ }^{42}$ Pero no más casta era la actitud de

\footnotetext{
${ }^{41}$ Véase PESO, op. cit., pp. 191, 274.

${ }^{42}$ Véase D. A. Kossoff, «El pie desnudo: Cervantes y Lope», en Homenaje a William L. Fichter, ed. A. David Kossoff y José Amor Vázquez, Madrid, Castalia, 1971, pp. 381-386; y A. Redondo, «Las dos caras del erotismo en la primera parte del Quijote», op. cit., pp. 258, 266-267.
} 
Marco Antonio que mostraba sus deseos de conocer, bíblicamente, se entiende, a Cleopatra: «Mirábala Antonio, como / el que conocer desea» (p. 430a).

Los criados no solo cuentan sus anécdotas amorosas con bastante ligereza sino que en su relación también reflejan su tendencia a la procacidad erótica. Así vemos cómo Sabañón, en Sin honra no hay amistad, demuestra sus habilidades lascivas para el galanteo, pues dice cómo tentó con los ojos y vio con los dedos a la hermana de Antonio (p. 297c). Aunque no se trata de una escena marcada por el humor, de forma muy similar, vemos cómo en La vida en el ataúd el dramaturgo vuelve a referirse a la relación carnal, de manera que las manos participan de la pasión amorosa. Así, dice Aglaes a Bonifacio, que se hace pasar por Candor: «Ojos las manos haciendo, tocándote lo he de ver» (vv. 1385-6). ${ }^{43}$ Pero, quizá, sea en esta pieza donde el cuerpo cobra una significación claramente erótica, pues observamos cómo el deseo carnal surge intensamente de la contemplación del cuerpo; de ahí que Aglaes, en un aparte, confiese la excitación que le produce el cuerpo del siervo Bonifacio:

(Demás de ser hombre bajo, ¡qué viles partes que tiene!)

Vete, vete. (En él no hallo

cosa buena; es monstruo, es fiera,

pero amor todo es milagros.) (vv. 716-20)

En La traición busca el castigo, Mogicón, que está discutiendo con Don Andrés, nada más empezar la obra, le pide perdón por su «impertinencia» de preguntarle una curiosidad, que es su modo de galantear. El hecho de que él mismo reconozca que se trata de una «impertinencia» nos pone sobre aviso acerca del tema un tanto indiscreto que trata, por la materia delicada, el amor erótico, y por importunar a su señor con asuntos personales. Mogicón quiere saber, en definitiva, por qué su señor galantea a todas las mujeres y en su planteamiento no falta alguna alusión de carácter erótico cuando le dice que lo ve descender «deste estado a otro más bajo» «porque sueles descender / desde el moño al estropajo» (233c): la connotación erótica se desliza porque el poeta opone estropajo a moño, de forma que el galán no sólo desciende de

\footnotetext{
${ }^{43}$ F. de Rojas Zorrilla, La vida en el ataúd, ed. R. R. MacCurdy, Madrid, Espasa Calpe (Colección Clásicos Castellanos), 1961.
} 
«estado», sino de lugar en las partes del cuerpo de la dama, desde la cabeza, concretado en el moño, al sexo, cifrado en el estropajo. ${ }^{44}$

Así vemos cómo el cuerpo es utilizado con cierta frecuencia por Rojas Zorrilla como un referente erótico. En Abrir el ojo hallamos otro chiste corporal cuando dialogan don Clemente y Cartilla refiriéndose a Doña Clara:

\section{DON CLEMENTE.}

CARTILLA.
Particular afición debo

doña Clara ya.

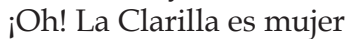

de mucho particular. (vv. 336-340)

El uso de la falsa etimología permite el juego de palabras, pues la particularidad que Don Clemente le debe a Clara es exagerada por su criado cuando Cartilla dice que es «mucho particular», ${ }^{45}$ es decir, de «mucho culo».

En la Numancia cercada hallamos otra alusión de signo erótico a través de la mención de rasgos corporales. ${ }^{46}$ Así, cuando Tronco sale disfrazado graciosamente para comprobar «de Olalla el amor y fe», se encuentra con su esposa que le pregunta por él y lo describe para que le diga si lo ha visto. ${ }^{47}$ En su descripción física hay algunas notas que tienen un marcado sentido erótico:

$$
\begin{aligned}
& \text { y fuera -mi fe os empeño- } \\
& \text { más ligero que un neblí, } \\
& \text { a no tener una pierna } \\
& \text { mayor que la otra un tris. (vv. 1712-1715) }
\end{aligned}
$$

Difícilmente podría haber elogio alguno en la cojera de Tronco, salvo que dicho rasgo escondiera alguna facultad especial, como es la que a lo largo

\footnotetext{
${ }^{44}$ Por otra parte, tal vez no sea excesiva la identificación de estropajo con estopa («Díxose estropajo del nombre Estopa, como si se dixera Estopajo», Autoridades), lo que facilitaría aún más el significado sexual de estropajo, como ratifica el proverbio popular, recogido por Orozco en su Teatro Universal de Proverbios: «El hombre es fuego / y la mujer estopa, / viene el diablo y sopla»; véase J. L. Alonso Hernández, «Claves para la formación del léxico erótico», Edad de Oro, IX (1990), p. 14.

${ }^{45}$ Luis de Góngora ofrece varios ejemplos del empleo de esta palabra con el mismo significado erótico: en el soneto que comienza « $\mathrm{iO}$ qué mal quisto con Esgueua quedo»: «Peon particular, quitado el parte"; o en el atribuido A unos mancebos que fueron iniciados del pecado nefando: «De dos vezinos tan particulares, / Que en su particular tienen cosquillas.»; Sonetos, ed. Biruté Ciplijauskaité, Madison, The Hispanic Seminary of Medieval Studies, 1981, pp. 339, 565, respectivamente].

${ }^{46}$ F. de Rojas Zorrilla, Numancia cercada, op. cit., pp. 78-79.

${ }^{47}$ Como ha señalado el editor de la obra (ibidem), se trata de una escena paródica «del bien conocido romance Las señas del marido, en que el marido, disfrazado, sostiene un diálogo con su mujer para probar su fidelidad».
} 
de la tradición culta y popular se le ha atribuido, la virilidad, lujuria, destreza sexual...48

Otra alusión erótica más evidente, de acuerdo con el contexto, radica ya en el propio nombre del gracioso, que ahora subraya su esposa: «Tronco se llama mi esposo, / y iqué tronco!» (vv. 1720-1721). El juego de palabras entre el nombre y el «tronco», permite, en esta ocasión, identificar el segundo término con el miembro viril del gracioso, que parece tener encantada a Olalla, ${ }^{49}$ a juzgar por el dulce sabor de su esposo: «sabroso como el anís».

Las alusiones al apetito o a los alimentos también son recurrentes en el teatro de Rojas Zorrilla para aludir al deseo o a la práctica erótica. En Los áspides de Cleopatra encontramos una escena entre los criados, Libia y Caimán, que parece tener connotaciones eróticas. Libia se queja de la prohibición de amar ordenada por Cleopatra en Egipto, lo que está en contra de la naturaleza. Ella admite que tal prohibición la ha llevado a desear a todos los hombres (p. 425bc). Así, la conversación entre los criados se desliza por la vertiente sexual, como ratifica la pregunta retórica de Caimán: «¿Habrá un poquito de empleo / para un amor vergonzante» (p. 425c); la alusión de Caimán que no come lo que pide cuando le da la mano y el brazo; Libia también dice que «la privación / es causa del apetito», ${ }^{50}$ Caimán quiere ser su amante; Libia alude a la prohibición del «humano apetito», en clara referencia al deseo o relación carnal; Caimán señala que si es quemado después del delito, refiriéndose al coito, no le importa; incluso Caimán quisiera ver quemadas a todas las mujeres, pues sería señal de que todos hubieran cometido el delito (pp. 425c-426a).

No cabe duda de la naturaleza lasciva del sentimiento amoroso de Aglaes, en La vida en el ataúd; de ahí que muestre sus dudas ante la conveniencia de despedirlo o de que siga a su servicio, como una prueba de Dios para castigar su arrogancia y «hacer mi albedrío esclavo / de un apetito tan vil» (vv. 54-55). Son constantes las referencias al deseo carnal que siente Aglaes por Bonifacio, como confiesa en este aparte:

\footnotetext{
${ }^{48}$ Véase J. Sepúlveda, «A propósito de La Lozana Andaluza: Los andares de Rampín», Voz y Letra, XIII, 2 (2002), pp. 115-146.

${ }^{49}$ En PESO (op. cit., p. 281) podemos comprobar cómo aparece troncho con el significado de miembro viril: «un cardillo de beatas, / para revelar secretos, / cuyo azucarado troncho / agua se hace de tierno».

${ }^{50}$ En la tradición literaria, ha sido frecuente el uso del término apetito con una significación erótica, como, entre otros, atestiguan PESO (ibidem, pp. 29, 30, 56, 183, 227) o J. A. Parr, «Erotismo y alimentación en el Burlador de Sevilla», Edad de Oro, X, (1990), p. 236.
} 
(Este me inquieta a un extraño amor. ¡Bárbaro apetito! ¡Corrida de imaginarlo estoy!) (vv. 704-6)

La relación amorosa de los criados, Mogicón e Inés, cobra mucho protagonismo en La traición busca el castigo. De hecho, incluso la mujer, Inés, ha mostrado su intención de seducir a Mogicón, en contra de la actitud pasiva que suelen tener las damas en el teatro áureo. Además, no se trata de un simple galanteo, sino una seducción que pretende culminar con la realización del acto sexual; una idea que parece no disgustar a Mogicón, como se deduce de su opinión, claramente libidinosa, sobre Inés: «que es moza de buena cala» (p. 245b). ${ }^{51}$

Desde esta perspectiva, premiar, como en la tradición del amor cortés, tiene un sentido más acorde con la recompensa sexual que tanto solicita el amante; a cuya concesión se muestra dispuesta, por supuesto, Inés, según confiesa en un aparte. Cuando Mogicón, en La traición busca el castigo, le dice «En dulce y suave lazo...», Inés se enfada (aun cuando se trate de una criada, su condición de mujer parece obligarla a aparentar, siquiera de forma hipócrita, cierto recato) acusando su suciedad por las connotaciones eróticas, y emplea la metáfora de comer y sobre todo de mesa para referirse a sus pretensiones carnales: ${ }^{52}$

Bribón, si queréis comer

amor en otero igual, idos, pesia tal, por tal

MOGICÓN. ¡Señora! a la sopa del querer.

INÉS. Andad, que me pesa. ¿Han visto lo que se atreve? ¿Que quiera un lacayo aleve comer en primera mesa! (p. 245b)

\footnotetext{
${ }^{51}$ En PESO (op. cit., pp. 126, 211) también puede atestiguarse el significado erótico de cala o cata. Pero calar («bajar las aves rápidamente sobre algún sitio o cosa determinada», Autoridades), que es un término habitual en el ámbito de la cetrería, también había aparecido en la poesía culta, y así puede verse, por ejemplo, en la Fábula de Polifemo y Galatea de Góngora, simbolizando la unión erótica entre Acis y Galatea: «paloma se caló, cuyos gemidos» (v. 319).

${ }^{52}$ El empleo de comer y de mesa con un sentido erótico aparece documentado en PESO en varias ocasiones (op. cit., pp. 2000: 94, 98, 104, 151, 263; 78, respectivamente); Keith Whinnom citaba el valor metafórico de comer como futuere en la poesía cancioneril; La poesía amatoria de la época de los Reyes Católicos, Durham, University of Durham, 1981, p. 36.
} 
Los criados no limitan su procacidad al chiste o al dicho erótico, sino que en algún momento los vemos resueltos a llevar a la práctica sus atrevimientos de corte sexual, sin los requiebros ni miramientos de sus amos. En Primero es la honra que el gusto, las sugerencias eróticas de los criados emanan, ya desde el principio, tan solo de sus nombres: Pepino y Flora, que, desde el campo léxico vegetal, evocan metafóricamente los órganos sexuales masculino y femenino. ${ }^{53}$ El contraste entre el refinamiento amoroso de los señores y la inmediatez carnal de los criados es presentado de forma simultánea por Rojas en un cuadro escénico, pues mientras vemos galantear a los primeros, Félix y Leonor, los segundos, en un aparte, también dialogan brevemente para pasar a la acción: Pepino, a través de las imágenes vegetales comentadas, propone a Flora mantener relaciones carnales, a juzgar por su respuesta (p. 443b). La réplica de Pepino tampoco deja dudas acerca de sus intenciones que son aceptadas por Flora, ya que ambos, como puede deducirse de la metáfora hortícola, que tanto juego ha proporcionado al tema amoroso, se marchan a consumar sus propósitos: «El Pepino enflorecerse / y la flor empepinarse» (443b).

Ciertamente, parece que la procacidad lingüística se da mucho más en el mundo de la servidumbre, que se manifiesta de forma más locuaz y menos cauta y galante. Las intenciones de los criados se reducen, sin más recatos ni miramientos, al deseo de mantener relaciones carnales sin otra pretensión supuestamente más elevada o encubridora de sus fines sexuales como la del matrimonio, y sin ningún tipo de rodeo, en forma de juego seductor o galanteo. Tal vez en ese ámbito resulte más fácil moverse o desarrollar el juego erótico o carnal que adquiere sobre todo una función cómica por su tono más directo, más licencioso y nada refinado; la relación carnal concebida como un acuerdo mutuo sin necesidad de sentimiento amoroso ni otros compromisos que conlleva el noviazgo o matrimonio.

A pesar de tratarse de una tragedia, en Progne y Filomena parece haber ocasión para la risa erótica que expresa la criada Libia. Ella se queja de los otros dos criados que la pretenden, Juanete y Chilindrón. El poeta usa el

\footnotetext{
${ }^{53}$ En PESO (op. cit., pp. 283; 14, 236) se recogen algunos ejemplos en los que Pepino y Flora están asociados metafóricamente con los órganos sexuales masculino y femenino, respectivamente. El motivo de las hortalizas de amor tuvo un gran cultivo en el Siglo de Oro, como demuestra la poesía de Diego Hurtado de Mendoza; véase Poesía erótica, ed. I. Díez Fernández, Archidona, Ediciones Aljibe, 1995; e I. Rada, «Expresión del erotismo en Hurtado de Mendoza», Edad de Oro, IX (1990), pp. 241-250.
} 
campo léxico de la comida, y en especial el juego entre dar y pedir -ambos con el sentido metafórico de futuere- para aludir a la insatisfacción de Libia con sus dos pretendientes: ${ }^{54}$

El galanteo es donoso;

no he de querer a ninguno,

porque es muy goloso el uno,

y el otro muy codicioso;

de los dos las mañas sé,

y dejarlos es preciso:

él me come cuanto guiso,

y él me pide cuanto ve.

Que no quiero les prevengo, quien me coma lo que tengo, que busco quien me regale; y a él pido, pues su error ve, que su codicia comida, que no busco quien me pida, sino solo quien me dé. (p. 42b)

Ante la duda de a quién elige, le preguntan y ella responde que a Juanete, y lo explica con otra alusión que también puede tener una connotación erótica: «Porque el goloso se harta, / pero el codicioso no» (ib.).

En el Siglo de Oro resultaba tópica la referencia a la realización física del amor a través del motivo, de larguísima tradición literaria, de la militia amoris. Así, en Los áspides de Cleopatra, vemos cómo Caimán, que está contando a Lépido, Irene y Octaviano, cómo ha sido el encuentro entre Marco Antonio y Cleopatra, termina su relación aludiendo al goce erótico de Marco Antonio y Cleopatra a través de la imagen del amor como una guerra que duró muchos días: ${ }^{55}$

\footnotetext{
${ }^{54}$ El sentido erótico de dar y pedir aparece frecuentemente en la literatura culta y popular, como se observa, por ejemplo en la letrilla de Góngora «Ya de mi dulce instrumento» (1595): «Si el pobre a su mujer bella / le da licencia que vaya / a pedir sobre la saya, / y le dan debajo della, / ¿qué gruñe, qué se querella / que se burlan de él los ecos? / Y ¿qué teme en años secos / si el necio a su casa lleva / quien en años secos llueva? / Coja, pues, en paz su trigo, / y digan que yo lo digo»; Obras completas, I, op. cit., p. 164. En PESO se recogen muchos ejemplos que ilustran dicho significado (op. cit., pp. 125, 129, 225; 56). Keith Whinnom había señalado el significado metafórico de pedir como futuere (op. cit.).

${ }^{55}$ Rojas Zorrilla recrea el tópico con el significado erótico en otras piezas, aunque sin el tono humorístico. En La vida en el ataúd [1961], la pasión irrefrenable que siente Aglaes la lleva a invitar a Bonifacio a que suba a su cuarto para consumar su deseo, como confiesa en un aparte, usando un lenguaje propio del tópico de la militia amoris: vv. 735-6 (La vida en el ataúd, ed. R. R. MacCurdy,
} 


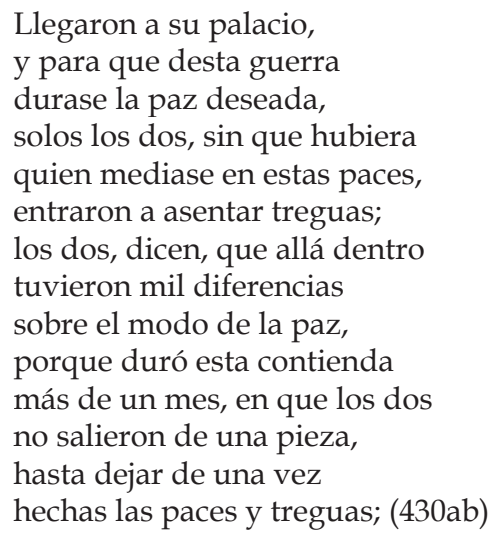

Otro uso del tópico con un sentido erótico lo vemos en la escena que en la Numancia cercada protagoniza la pareja de graciosos Olalla y Tronco, que Sale armado graciosamente y Olalla teniéndole. ${ }^{56}$ Tronco le aconseja a Olalla que, cuando vuelva de la guerra, «no me habléis con furia tanta, que podrá ser...»; ante el suspense de Tronco, le pregunta Olalla, «¿Qué ha de ser?», y aquel le responde, «Que os meta un palmo de espada» (v. 1246): el suspense y la reticencia de Tronco - unidos a los supuestos insultos a Tronco, al que ha llamado asno en varias ocasiones - no hacían sino crear las expectativas del chiste erótico que, finalmente, revela el criado en su respuesta, pues meter y espada ${ }^{57}$ enfatizan la referencia al acto sexual.

El campo léxico del juego resultó un espacio común en el Siglo de Oro en el que los dramaturgos hallaban expresiones para referirse al amor erótico. Así, en Los áspides de Cleopatra vemos cómo Caimán describe la participación que se producirá en la batalla que, desde luego, él quiere contemplar de lejos (p. 435a), de acuerdo con el miedo ancestral de los criados. Ahí se puede observar alguna alusión que puede tener un significado erótico: «Lindo tahur

Madrid, Espasa Calpe, Colección Clásicos Castellanos, 1961); y en Cada cual lo que le toca podemos leer el eco de la conocida imagen petrarquista, usada por Góngora, del lecho como «campo de batalla»: "el lecho en que descansais / es la palestra en que lidio", vv. 333-4 (Cada cual lo que le toca y La viña de Nabot, en op. cit.), que aparece de forma similar en El más impropio verdugo: «Sin que el lecho que tanto me recrea, / campo a mis ansias de batalla sea» (p. 172a).

${ }^{56}$ F. de Rojas Zorrilla, Numancia cercada, op. cit., p. 58.

${ }^{57}$ En PESO podemos comprobar el significado erótico de espada como 'miembro viril' (op. cit., pp. 241-242). No creo necesario insistir en el valor sexual de meter. 
es Antonio, / con todo el mundo se tira». En efecto, tahur se ha aplicado al campo semántico del amor, para referirse al amante experimentado y díscolo; un significado erótico que cobra más fuerza porque el poeta ha subrayado la promiscuidad de Marco Antonio, «con todo el mundo se tira», pues el verbo tiene el sentido latino de futuere, como se atestigua en PESO. ${ }^{59}$

En Sin honra no hay amistad, Rojas ha empleado también la misma palabra refiriéndose a una dama, cuando Sabañón pregunta a Melchor y Antonio por qué están así: «¿te hizo alguna alicantina / dama, tahura de amor?» (p. 295b), aludiendo a la mujer muy experimentada, $\mathrm{y}$, por lo tanto, falsa y embaucadora, es decir, una prostituta.

Otro chiste erótico que se basa en el campo léxico del juego aparece en Abrir el ojo y corresponde a Juan que se está quejando del alquiler de la casa que disfruta Doña Clara a la que pretende. Marichispa le dice que él es una pieza más de la casa. Juan recoge el comentario y hace el señalado chiste erótico:

$$
\begin{array}{ll}
\text { JUAN. } & \multicolumn{1}{c}{\text { Me contento }} \\
& \begin{array}{l}
\text { con ser pieza en esta casa, } \\
\text { por serlo de este tablero. } \\
\text { MARICHISPA. }
\end{array} \\
& \text { ¡Ay, que jugó del vocablo! } \\
\text { ¡Qué donosura! (vv. 962-966) }
\end{array}
$$

Juan acepta encantado ser una pieza si eso le permite estar sobre el tablero, que sería Clara.

Matea, en Lo que son mujeres, cuando intenta explicar que hay que querer bien a los hombres, ofrece una justificación basada en distintas habilidades varoniles: en el galanteo («desempiedra») ${ }^{60}$ o en varios juegos o deportes («toreo», defensa y «esgrima»). Ahora bien, en esas palabras de Matea no cabría descartar, habida cuenta del tono desenfadado y un tanto hiperbólico, una alusión de carácter erótico, pues las habilidades varoniles o instrumentos que menciona tradicionalmente han estado relacionados con la actividad sexual:

¿Qué gusto puede tener quien quiere mal a los hombres?

A un hombre de lindo talle,

dí, ¿quién sabe hacer desprecio

\footnotetext{
${ }^{58}$ Véase PESO, op. cit., p. 292.

${ }^{59}$ Ibidem, pp. 59 y 72.

${ }^{60}$ F. Pedraza, «Variantes del galanteo en Rojas Zorrilla», op. cit., p. 119.
} 


$$
\begin{aligned}
& \text { de verle pisar tan recio } \\
& \text { que desempiedra la calle? } \\
& \text { Con recato y con decoro, } \\
& \text { cuando empuñan el rejón, } \\
& \text { ¿quién no cobrará afición } \\
& \text { a un hombre que mata un toro? } \\
& \text { ¿Qué mujer no cobra amor } \\
& \text { a aquel que en lid concertada } \\
& \text { obra con la negra espada, } \\
& \text { y con la blanca mejor? (p. 202b) }
\end{aligned}
$$

Ciertamente, la significación erótica de talle ya se ha comentado; pero en dicho contenido inciden pisar, rejón, espada, como atestiguan los textos de la época. ${ }^{61}$

En las tradiciones del amor cortés y petrarquista los poetas acudían a las metáforas ígneas principalmente para referirse al sentimiento amoroso; unas metáforas que los poetas también empleaban, en no pocas ocasiones, con un claro sentido erótico. En Donde hay agravios no hay celos, vemos cómo la criada Beatriz cuenta cómo encontró a Lope que había entrado en casa de Doña Inés. En su relato alude al deseo carnal de Don Lope, al que encerró en el balcón para que no lo viera el padre de Inés, lo que Beatriz justifica que lo hizo para apagar su incendio, es decir, su deseo carnal:

cerré el balcón por de dentro,

$\mathrm{y}$, al dejalle por de fuera,

todos sus deseos puse

al sereno como velas. ${ }^{62}$ (vv. 516-520)

Al comienzo del tercer acto, se han quedado a oscuras Doña Juana, Doña Inés, Águeda y Sabañón, éste encuentra en la alacena una caja, yesca, eslabón y pajuelas, y le pregunta a la criada con tono malicioso: «¿Sabes encender? que a mí / nunca encenderme has sabido» (p. 311c). ${ }^{63}$ Cuando la encienden, comenta Águeda a Doña Inés, también con claro contenido erótico:

\footnotetext{
${ }^{61}$ El vocabulario relacionado con la práctica del galanteo (como pisar [«En las aves, cubrir el macho a la hembra», $D R A E]$ ), la guerra o el deporte (espada) y el entretenimiento (rejón), tenía una clarísima relación metafórica con el erotismo, en concreto con lo que puede llamarse «embestida viril»; A. Redondo, «Las dos caras del erotismo en la primera parte del Quijote», op. cit., pp. 255-256.

${ }^{62} \mathrm{El}$ sentido de velas podría ser el de 'centinelas' o 'guardias' que están vigilando en el exterior.

${ }^{63}$ Los mismos términos encontrados (yesca, eslabón, pajuela), pertenecientes al campo semántico del fuego, inciden en el significado metafórico de la unión erótico.
} 
Ya encendió.

La pajuela y el pabilo

(Encienden)

pegaron, porque ella es hembra

y él es macho muy castizo. (ib.)

No cabe duda de que, en La vida en el ataúd, Aglaes siente un deseo intenso de gozar sexualmente a Bonifacio. Tampoco es frecuente en el teatro áureo -y Rojas en este aspecto es de nuevo una excepción- que las damas confiesen tan abiertamente sus íntimos deseos eróticos ante su objeto de amor. La idea del fuego como metáfora del amor tiene una larguísima tradición literaria, pero aquí el fuego amoroso se emplea sobre todo con su sentido sexual, como se observa, por ejemplo, en el aparte de Aglaes:

(Rayo este villano ha sido

del amor, pues me encendió,

cuando el cuerpo me tocó,

el alma)

(...)

¡Loca estoy! (vv. 569-79)

El encuentro nocturno de Bonifacio y Aglaes, según la invitación de la dama, se produce con un subido tono erótico que se expresa a través de la metáfora del fuego para referirse realmente al deseo carnal.

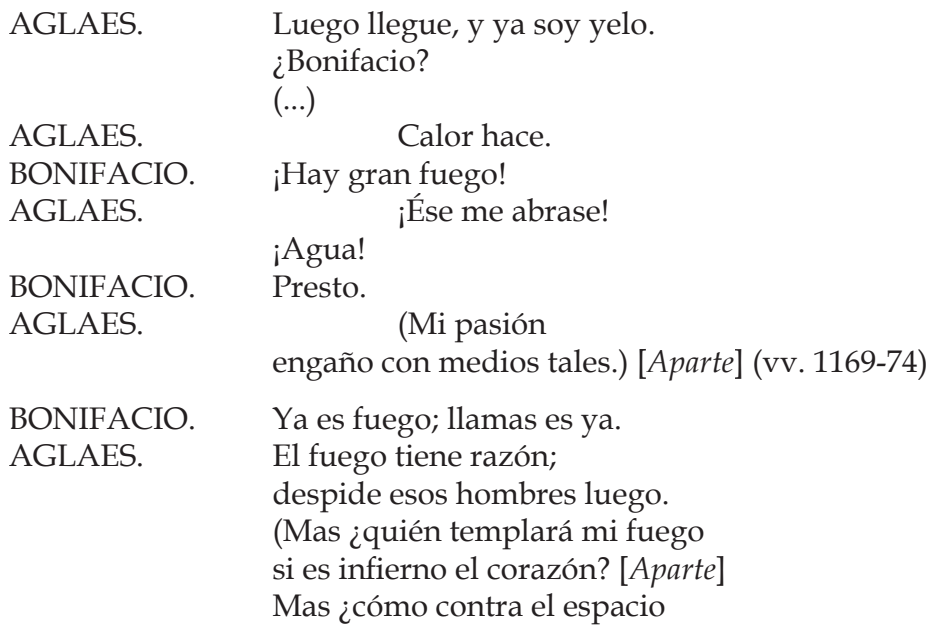


voy dilatando esta gloria?

Haya en el mundo memoria

de Aglaes y de Bonifacio.) (vv. 1201-1209)

En Cada cual lo que le toca vemos de nuevo la referencia a las metáforas ígneas con el sentido erótico cuando D. Fernando confiesa a Isabel que su deseo carnal («fuego») no se puede apagar:

Ya, Isabel, ni tu desdén

ni mis atenciones valen

para apurar este fuego

que en mudas cenizas arde. (vv. 3153-56)

En La traición busca el castigo, los amores de Don Andrés son siempre lascivos y nunca tienen como fin el matrimonio. Por eso, quizá, dice a su amigo Don Juan que no le gustaría que se casara (p. 237c). En la exposición de sus amores tanto García como Don Juan se han expresado con decoro. Cuando Don Juan dice a Don Andrés que dos hombres pretenden a su dama, alude a la consecución del amor que pretenden y se trata de una clara alusión erótica:

los dos intentan

del fuego en lo insuperable

arder con nueva materia. (p. 237c).

\section{Metáforas Verbales y REFranes}

Si hay una palabra que, de forma indudable, alude al deleite carnal es el verbo gozar. Su referencia a las relaciones sexuales y, por supuesto, al coito, ha sido explotado a lo largo de toda la literatura del Siglo de Oro. ${ }^{64}$ Así pues, no parece caber duda de que el verbo gozar no solo se refiere a la felicidad

\footnotetext{
${ }^{64}$ En especial en aquella literatura que podemos considerar más explícita o descarada, como se ve, por ejemplo, en el soneto «Primero es abrazalla y retozalla», donde leemos, en el v. 8, «después viene el deleite de gozalla», o en el soneto que comienza «- ¿Qué me quiere, señor? Niña, hoderte» (PESO, op. cit., pp. 11 y 213, respectivamente). Pero también en los textos más cultos, incluso cultistas, y en el ámbito de la expresión idealista del amor, expresada de forma más recatada, la aparición de gozar introduce un evidente tono erótico; como se observa, por ejemplo, en el soneto juvenil de Góngora «Mientras por competir con tu cabello»; y sobre todo en el conocido soneto de Quevedo «" ¡Ay, Floralba! Soñé que te..., ¿dirélo? / Sí, que pues sueño fue, que te... gozaba"»; o en el que se le atribuyó: «Quiero gozar, Gutiérrez; que no quiero / tener gusto mental tarde y mañana». El significado erótico de gozar en la poesía del siglo XV había sido señalado por K. Whinnom; La poesía amatoria..., op. cit., p. 36.
} 
espiritual derivada del amor correspondido, sino que hace referencia a las deliciosas relaciones carnales de los amantes. Y con este significado aparece en numerosísimas ocasiones en el teatro de Rojas Zorrilla.

La vida en el ataúd es, tal vez, la obra de Rojas en la que con más claridad se observa la aparición del erotismo y del deseo carnal. Resulta curioso que, de forma paradójica, se trate de una comedia religiosa. Sin embargo, no hay que olvidar que lo religioso y lo erótico, que aparecen unidos con frecuencia en la tradición literaria, también ha dejado algunos ecos en el teatro de Rojas. En todo caso, vemos, ya en el primer acto, cómo la dama Aglaes siente un irrefrenable deseo erótico ante el siervo Bonifacio:

$\begin{array}{ll}\text { BONIFACIO. } & \text { Aquí estoy a tus pies puesto. } \\ \text { AGLAES. } & \text { ¡Corrida estoy! } \\ \text { BONIFACIO. } & \text { ¡Yo perdido! } \\ \text { AGLAES. } & \text { Vil, ¿quién eres que has venido } \\ & \text { a ser sombras Arnesto? } \\ & \text { ¿Quién la idea ha fabricado, } \\ & \text { cuando gozarlo deseo? } \\ & \text { ¿Así en mis brazos te veo, } \\ & \text { despierto y no imaginado? (vv. 537-44) }\end{array}$

Otro rasgo contradictorio para el teatro de la época es la pasión que despierta un criado en dos damas principales, pues también se enamorará de él Milene, e incluso ambas disputarán por conseguir su amor. De hecho, hasta la propia Aglaes parece arrepentirse de haber abrazado a un criado, y quiere despedirlo cuanto antes, pues quiere librarse de caer en la tentación física: «mas quiero librarle aquí / sólo por librarme dél» (vv. 601-602). Milene también se ha enamorado de Bonifacio y se muestra dispuesta a conseguir su favor sexual, como confiesa claramente:

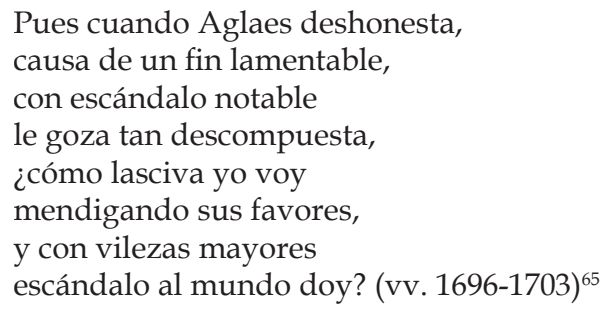

${ }^{65}$ Otros usos de gozar con un evidente significado erótico aparecen en Peligrar en los remedios (pp. 351c, 354c); en Primero es la honra que el gusto (p. 441b); o en Los áspides de Cleopatra (p. 432b). 
En La traición busca el castigo, encontramos otra metáfora verbal que parece tener una connotación erótica. Se trata del chiste que hace Mogicón cuando defiende que el hombre debe casarse con una mujer fea: «que saben andar a pie / y comer vaca y carnero» (p. 243a). En efecto, es tradicional en la literatura el sentido erótico de andar, como metáfora de futuere. ${ }^{66}$ En PESO se recoge pie con un sentido erótico (que Rojas usa en otro texto): «Tú vas a caballo y yo voy a pie; / vete más de espacio y te alcanzaré». ${ }^{67}$ La recomendación de casarse con una mujer fea parece basarla Mogicón en su aceptación de los cuernos, de ahí que sepa "comer vaca y carnero». ${ }^{68}$

Por supuesto, tampoco podía faltar algún chiste contra las cortesanas y su tópica fama de mujeres lascivas y libidinosas: «Mozuelas de la Corte, todo es caminar, / Unas van a Huete y otras a Alcalá» (p. 32a); caminar tiene el sentido de futuere, como se atestigua en PESO. ${ }^{69}$

En No hay ser padre siendo rey, vemos cómo los criados, Clavela y Coscorrón, aparecen en escena contando chismes de sus amos. Ambos sirven a la duquesa Casandra y murmuran («La lengua me hace murmur», v. 541, como gustaba decir a Rojas) acerca de los amoríos de los señores (desde luego, ese tema de corte satírico burlesco de la crítica de la servidumbre a los señores, que aparecía desde el Asno de oro, el Lazarillo, a los romances de Góngora o Quevedo, ha sido diluida por Rojas en el aspecto amoroso, lo que en parte resulta lógico por el tema y tono de la comedia). Clavela le cuenta cómo ella, haciéndose la dormida, vio cómo su ama, la Duquesa, le abrió una noche la puerta de su habitación al Infante Alejandro, y comenta con malicia:

$$
\begin{aligned}
& \text { Ella, quedo y más quedito, } \\
& \text { como la que va pisando } \\
& \text { los huevos de las despensas, } \\
& \text { que esotros ya se acabaron; (vv. 579-582) }
\end{aligned}
$$

Coscorrón le responde que «no hay que proseguir, / supuesto que se han entrado», que significa obviamente que se metieron en la habitación, pero

\footnotetext{
${ }^{66}$ Así, PESO ofrece varios testimonios; op. cit., pp. 20, 36, 40, 195, 271.

${ }^{67}$ Ibidem, p. 260.

${ }^{68}$ Con un uso similar aparecía en un soneto de Quevedo: «Casóse la Linterna y el Tintero»; I. Arellano, Poesía satírico burlesca de Quevedo, Pamplona, Universidad de Navarra, 1984, pp. 485486. Ahora bien, no puede descartarse que el significado erótico de carnero aluda a la habilidad de la mujer fea con el sexo masculino, a juzgar por el testimonio recogido en PESO: «No me case mi madre con pastelero, / porque pica la carne en el carnero» (op. cit., p. 255).

${ }^{69}$ Ibidem, p. 79, 187, 198, 236.
} 
también puede tener todavía un significado más claramente erótico, con el sentido de «penetraron», de modo que no es necesario abundar más en el asunto. ${ }^{70}$

Clavela justifica la actuación de su ama y emplea una metáfora del campo semántico textil que suele referirse a su acción de chismorrear («Hemos urdido una tela, / un vestido hemos cortado»), pero, además de criticar a su señora, parece que los criados se estaban dedicando a la actividad erótica, lo que refieren a través de otra metáfora perteneciente al campo léxico de la costura: «porque yo lo abotonaba / y esta le estaba ojalando» (p. 392b). ${ }^{71}$

En Los bandos de Verona el criado Guardainfante nos ofrece una imagen degradada de la mujer que parece quedar simplificada en dos grupos: «las del pido» y «las del toma» (p. 370bc), ${ }^{72}$ en clara referencia a su disponibilidad sexual. En Abrir el ojo, Doña Hipólita, que está enfadada con Don Clemente, para darle celos le dice que se irá «Al Prado, que hoy tengo coche» (v. 251); ella había dicho anteriormente que no era «dama de coche y calle Mayor», en referencia a las que usaban el coche para las prácticas amatorias. Previamente, también le había marcado la hora de su «toma», las doce (v. 247): tomar tiene un doble sentido, pues se refiere, inocentemente, a la hora de la comida, pero -como se señaló más arriba - también a la hora de la práctica sexual. ${ }^{73}$

En Lo que son mujeres vemos cómo Don Roque ofrece una sátira de tipos, entre los que sobresale la crítica al marido que reprocha a su mujer que haya sido licenciosa en la calle cuando él no ha sabido contentarla en casa. Un chiste erótico que vuelve a basarse en la metáfora verbal de dar / pedir (p. 210a):

Traiga o no traiga mi dama la pollera o faldellín, ¿por qué la he de pedir cuenta de lo que yo no la di?

\footnotetext{
${ }^{70}$ PESO recoge numerosos testimonios de entrar con el evidente sentido erótico (ibidem, pp. 62, 70, 191, 196, 226, 276, 294, 296).

${ }^{71}$ De hecho, Góngora, en su romance Tendiendo sus blancos paños, nos presenta a un galán en cuyo atrevido parlamento usa los sustantivos botón y ojal con un claro sentido erótico: «Violante, que un tiempo fuiste / pelota de mi trinquete, / de mis botones ojal / y de mis cintas ojete»; Obras completas, I, op. cit., p. 140.

${ }^{72}$ PESO ha recogido dos testimonios, entre los muchos que existen en el Siglo de Oro, de tomar como metáfora verbal de la relación carnal; op. cit., pp. 40, 96.

${ }^{73}$ Además de los testimonios que ofrece PESO (ibidem, pp. 40,96) del valor erótico de tomar, un buen ejemplo lo podemos leer en el Tomar de las mujeres del poeta sevillano Juan de Salinas, Poesías humanas, ed. H. Bonneville, Madrid, Castalia, 1987, p. 523.
} 
En Lo que quería ver el marqués de Villena, el criado Zambapalo dice al Marqués sobre la cueva del Mágico Fileno y las mujeres y hombres que entran:

Estas:

la que desea saber, más de ambiciosa que tierna, si ha de volver el galán que la ofreció la pollera, porque ya dejó tomada la medida de la tela. La que perdió a Jazminillo, su perro, y saber desea si ha de hallarle, siendo un perro cosa que hallará en cualquiera. (p. 328c).

El sentido erótico radica en tomada la medida, una expresión que en el Siglo de Oro se usaba como metáfora de la relación carnal, como atestigua PESO. ${ }^{74}$

En La vida en el ataúd, Aglaes expresa su deseo erótico a Bonifacio a través de la metáfora verbal ganar-perder:

Dame los brazos; que quiero ganar en ellos el alma, pues el alma perdí en ellos. (vv. 1395-7).

La metáfora verbal de perder, tan frecuente en la poesía amorosa del Siglo de Oro, para referirse al enamoramiento, adquiere ahora también un sentido claramente erótico, pues la alusión al pecado por el deseo carnal resulta clara. ${ }^{75}$

En la Numancia cercada hallamos otra genuina metáfora verbal que tiene un valor erótico, como se ha ratificado a lo largo de la tradición literaria. ${ }^{76} \mathrm{Se}$ trata de moler, con el significado de copular, ${ }^{77}$ un sentido que queda subrayado

\footnotetext{
${ }^{74}$ «Las que a mi tienda se llegan, / como es negra conocida, / mientras tomo la medida, / con la maestrilla juegan» (op. cit., p. 131).

${ }^{75}$ Keith Whinnom había señalado el valor metafórico de perder como futuere en la poesía cancioneril; La poesía amatoria..., op. cit., p. 36. La paradoja ganar-perder, por otra parte, tuvo un larguísimo recorrido literario en el Siglo de Oro, como atestigua su empleo en el Cántico espiritual de San Juan de la Cruz: «Ya cosa no sabía, / y el ganado perdí que antes seguía»; «que, andando enamorada, / me hize perdidiza y fuy ganada»; Poesía, ed. D. Yndurain, Madrid, Cátedra, 1984, pp. 211-212.

${ }^{76}$ F. de Rojas Zorrilla, Numancia cercada, op. cit., p. 80.

${ }^{77}$ En PESO (op. cit., pp. 265-266) podemos ver un par de ejemplos de moler con este significado. Véase A. Redondo, «De molinos, molineros y molineras. Tradiciones folklóricas y literatura en la España del Siglo de Oro», en Literatura y Folklore: problemas de intertextualidad. Actas del Segundo
} 
por la palabra que sigue a continuación, palos -cuyo sentido erótico ya ha sido comentado-, de forma que la expresión que Tronco dice a su esposa, cuando acaba de comprobar que ella (que, según confesará más adelante, está fingiendo para hacerle rabiar) está dispuesta a casarse con el primero que encuentra, una vez que lo cree muerto, resulta claramente sexual: «No hay alguno por ahí / que la muela a palos?» (vv. 1165-1166).

En Primero es la honra que el gusto, el deseo de Don Juan de conseguir la correspondencia amorosa de Leonor lo expresa con una metáfora náutica, que no está exenta de una sugerencia erótica: ${ }^{78}$ «En el puerto de su pecho / se abriga mi nave», como así lo interpretó Pepino a continuación en un aparte: «No es nada lo que le ha dicho, / poco turbio es el don Juan» (p. 446b).

Pero, sin duda, el compendio más exhaustivo y novedoso de las metáforas verbales con significado erótico lo ofrece Rojas Zorrilla en Lo que son mujeres. Gibaja entrega una letra, que es un soneto, para una academia en el que aconseja cómo debe actuar la mujer con los hombres, donde no faltan alusiones de tipo erótico, desde el elocuente término con el que se dirige a la dama, ninfa, que tradicionalmente significa 'prostituta'79 (p. 210bc):

A tus amantes (ninfa vil) repástalos, y en regalada cama incasta, acuéstalos, búscalos, enamóralos, recuéstalos, preténdelos, escóndelos y engástalos.

A todos castos con fervor descástalos, a todos peros en tu cesta encéstalos; aunque no te molesten, tú moléstalos; aunque no te embanasten, tú embanástalos.

Por cuatro o cinco endrinas, Dina, endrínalos; en ocho o nueve cubas, Cuba, enmóstelos; con doce o trece sustos, Dama, asústalos;

Symposium Internacional del Departamento de Español de la Universidad de Groningen, Salamanca, Universidad, 1983, pp. 101-115.

${ }^{78}$ En Primero es la honra que el gusto el poeta vuelve a usar las metáforas náuticas para referirse a la debilidad moral de las hijas en relación con el asunto amoroso. Así, Don Rodrigo subraya la naturaleza frágil de las hijas empleando, como ya ha hecho en otras ocasiones, las metáforas náuticas: «Las hijas, don Félix, son/ (...) / ciegas en su juventud, / no saben aconsejarse / con la prudencia, y como es / su naturaleza frágil, / en el piélago de afectos, / y ocasiones naufragantes, / peligran; joh! tema cuerdo / el piloto destas naves: / desvélese providente, / prevéngase vigilante, / que tiene para esperar / poco feliz su pasaje, / mucho que las aventure / y nada que las resguarde» (p. 444ab).

${ }^{79}$ Véase J. Sepúlveda, «Erotismo y mitología en la poesía satírico-burlesca de Quevedo», op. cit., p. 41. 
Llámalos, amonestálos, inclínalos, abrásalos, enciéndolos y tóstalos, enfráudalos, engáñalos y embústelos.

Otro de los procedimientos retóricos que Rojas Zorrilla emplea para conseguir una significación erótica es la ruptura de sistemas que el poeta provoca en refranes, frases hechas o clichés. Además del ejemplo visto más arriba del refrán transformado en Cada cual lo que le toca, en La traición busca el castigo, Mogicón llega a casa de Leonor con Don Juan para postularse como su amante y cumplir el pacto alcanzado con Don Félix de casarse con ella. El gracioso pretende usar un lenguaje ritual que ignora y se equivoca dando lugar a expresiones indecorosas: "para tomar posesión / de su mujer» (p. 240a). La confusión del criado produce el chiste lascivo con el fin de provocar la risa.

En Sin honra no hay amistad, el gracioso Sabañón cuenta a Don Antonio cómo lo sorprendió el hermano de la dama a la que pretende Don Antonio, y se vio obligado a meterse debajo de un bufete, y Aguedilla, la criada lo sacó y acabaron metidos los dos en una despensa, y Sabañón aclara, a partir del refrán «hablar largo y tendido», que no pasó nada entre ellos:

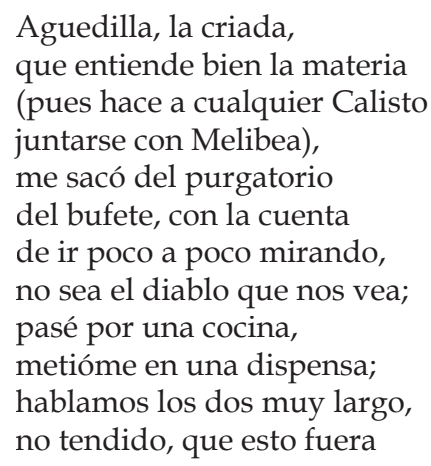

decir que fui de su honor comunero de la legua; y es muy honrada Aguedilla, y a no ser porque se prenda de todos los que la dicen cualquier palabra tierna; a no ser un poco falsa, y dos pocos alcahueta; a no beber algo más de lo ordinario, ser fea, ser corta de talle y sucia, no hubiera mujer como ella. (305bc).

El refrán que popularizó Góngora en su letrilla juvenil Ándeme yo caliente / y ríase la gente, ${ }^{80}$ levemente modificado, es puesto en boca de Aglaes para expresar su disposición a seguir su pasión amorosa, aunque no se trate de un igual, y marcharse con Bonifacio, incluso aun reconociendo la naturaleza vil de su amor:

\footnotetext{
${ }^{80}$ Se trata del refrán 2526 del Vocabulario de refranes y frases proverbiales (op. cit.).
} 


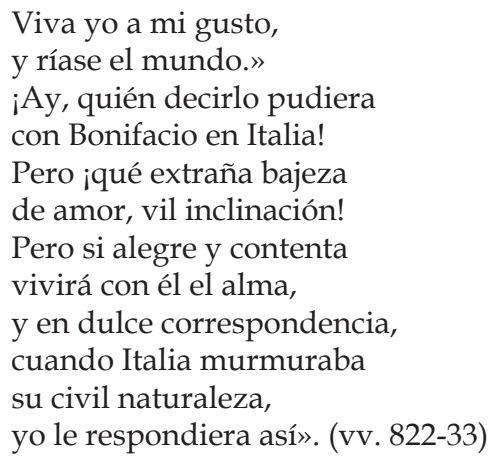

En El más impropio verdugo, Cosme ha presenciado cómo Alejandro se ha metido en casa de Diana y después aparece por ahí también su hermano Carlos, coincidiendo ambos, hace una alusión que parece tener un contenido sexual: «Deben de ser muy carnales / estos hermanos» (p. 179a).

\section{Conclusión}

La simple lectura de gran parte de las obras dramáticas - no se han tenido en cuenta las escritas en colaboración, ni las atribuidas - de Rojas Zorrilla pone de manifiesto la presencia del erotismo como un motivo destacado de su teatro. Puede decirse que, tal vez, ninguna de sus comedias nos ofrezca el tema del amor carnal desde una perspectiva exclusivamente celebrativa. ${ }^{81}$ Lo más que podría sugerirse, en este sentido, de un Rojas ajeno a la condena o censura moral de lo erótico sería la recreación, a modo de relación costumbrista, de los ambientes promiscuos y licenciosos, que no son vistos en ningún momento desde una mirada inquisitiva, sino que han sido recreados desde una contemplación, si no cómplice, comprensiva y alegre, como sucede en la que tal vez sea su obra más atrevida, Abrir el ojo.

Así, pues, no nos encontraremos con una dramaturgia que, en rigor, pueda ser considerada erótica, en el sentido de que nos presentara el amor carnal desde una perspectiva alegre y complacida, incluso teniendo la posibilidad de ver en las tablas algunas de esas prácticas amatorias. Sería impensable, lógicamente. Lo erótico queda reducido, desde esta óptica, a las

\footnotetext{
${ }^{81}$ Como había señalado Díez Fernández: «resulta difícil imaginar una obra dramática en la España de los Siglos de Oro que tuviera como tema central el juego erótico y lo expresara de manera abierta»; La poesía erótica, op. cit., p. 35.
} 
relaciones de encuentros amorosos. La técnica de la relación de aquello que no se ve en las tablas, o sea, la ticoscopia, permite que el espectador o lector imagine la escena del acto carnal, consentido o forzado. Pero, en su inmensa mayoría, lo que hemos encontrado ha sido una numerosa presencia de alusiones o referencias de carácter erótico, que Rojas ha realizado de acuerdo con los procedimientos habituales de la literatura de la época, aunque, en ocasiones, siendo mucho más atrevido que sus coetáneos. En todo caso, lo que resulta de esta lectura del teatro de Rojas es la presencia de un importante corpus de motivos eróticos que lo convierte en el poeta que más y, quizá, mejor, ha tratado el amor carnal.

Quizá pueda decirse que Rojas Zorrilla también se distancia, si no se diferencia abiertamente, de sus coetáneos en el tratamiento del tema erótico. Tal vez, el aspecto más llamativo sea que, en no pocas ocasiones, el poeta no suele tratar lo amatorio con una finalidad censoria, es decir, no hay un tono tan condenatorio, como se puede dar en Quevedo, de las prácticas amatorias. Rojas parece mantener una actitud serena ante la materia erótica. De hecho, Abrir el ojo es un ejemplo sobresaliente de cómo recrear los atrevimientos sensuales y eróticos sin ánimo condenatorio, un espíritu que no solo no aparece sino que queda al margen por completo frente a la realidad licenciosa y alegre que se muestra en las tablas. Pero, además, no faltan escenas en algunas obras en las que se aprecia el triunfo pleno del amor erótico. ${ }^{82}$ Bien es cierto que el poeta recrea tales momentos a través de las relaciones de sus personajes, que, eso sí, actualizan y reviven el placer pasado en el momento de contarlo.

El placer erótico resulta común, obviamente, a mujeres y hombres. Quiero decir que esa actitud comprensiva de Rojas al mostrarnos, sin censura, el encuentro carnal y el triunfo amoroso, afecta por igual a hombres y mujeres, de modo que ambos toman la palabra al recrear placenteramente las experiencias amatorias, sin que caiga la condena moral sobre las mujeres y la exculpación a los hombres.

Una característica que se observa en el tratamiento de lo erótico en el teatro de Rojas es la habitual exclusión del término directo que alude al cuerpo o a las actividades sexuales. Rojas no suele referirse de forma explícita, es decir, con una terminología coloquial, y mucho menos plebeya, ni a los

\footnotetext{
${ }^{82}$ Son objeto de estudio en el trabajo, ya mencionado, que se haya en prensa, sobre erotismo y violencia en el teatro de Rojas Zorrilla.
} 
miembros o elementos del cuerpo ni tampoco a las relaciones carnales. Desde luego, en una especie de pudor o de pretensión estética, Rojas siempre evita el taco y la palabra malsonante. Así, pues, se refiere a las experiencias amatorias, deseadas o cumplidas, y al cuerpo, a través de los habituales recursos o procedimientos expresivos que le brinda la tradición literaria o popular (alusión y elusión, tropos, rupturas de sistema, expresiones coloquiales, etc.), de forma que establece una complicidad con el espectador / lector que debe participar en la interpretación de la escena, y concretamente de la intención del poeta.

Enun sentido similar, también se observa cómo Rojas ofrece un tratamiento elegante del tema erótico, y no solo por lo que se acaba de comentar acerca de la omisión de la palabra malsonante o del término grosero, sino también porque no suele ofrecer una imagen degradada o deformada, satírica o grotescamente, de las relaciones amatorias, ni siquiera cuando éstas se han consumado a través de la fuerza o la violencia. El castigo final que padece el violador será la forma indirecta, en todo caso, de que el espectador saque sus propias conclusiones. Son los propios personajes, lógicamente, los que cuentan los hechos. Cuando son los criados los que hacen sus burlas y chistes eróticos tampoco lo carnal sale envilecido ni afeado; su vis comica puede basarse en la exageración, a veces en lo ridículo, dentro de su afán de provocar el humor, pero nunca persiguen este fin a través de la deformación violenta, asquerosa ni repugnante.

No es fácil adentrarse en el terreno de la explicación o interpretación de las causas o motivos que pudieron llevar a Francisco de Rojas a ofrecer un muestrario tan amplio del tema erótico en su dramaturgia. Desde luego, cualquier explicación no deja de ser una mera conjetura, habida cuenta de que no hay ningún testimonio del autor que pueda darnos la respuesta, y por ello es susceptible de estar equivocada. No se podría obviar el gusto personal del poeta por el tema de marras, pero tampoco sería inoportuno omitir el afán novedoso que perseguía, unido al gusto y a la tendencia que demostraba continuamente de llevar su teatro a un terreno de experimentación y de extremosidad desde diferentes perspectivas. En este sentido, la plasmación de lo erótico, a través del lenguaje, de la imaginación, de la representación, quizá fuera, entre otros, uno de esos instrumentos en los que sustentar su intento de resultar atractivo a un público cada vez más exigente y anhelante de novedades. Cómo explicar si no, por ejemplo, la obsesiva frecuencia con la que aparecen los intentos de violación o la consumación de la violación en su teatro; o cómo justificar, de otro modo, las continuas didascalias que 
especifican la presencia en las tablas de mujeres medio desnudas ${ }^{83} \mathrm{o}$ ticoscopias que recrean la aparición de mujeres bañándose desnudas, brujuleadas por la mirada de hombres que, excitados, las contemplan, y un público que, tal vez no menos animado, ávidamente las imagina.

El tratamiento de Rojas Zorrilla del tema amoroso, en su vertiente, quizá, más extrema, el erotismo, termina plegándose a ese gran juego paradójico que el Barroco muestra: la apariencia frente a la realidad. Así, desde un punto de vista aparente o superficial, el poeta lleva las relaciones amorosas a sus últimas consecuencias: las mujeres expresan sus deseos de amar y, en no pocas ocasiones, lo consiguen; los hombres también acaban obteniendo la recompensa erótica al gozar el objeto de sus deseos, bien que en numerosos casos por el ejercicio de la fuerza; todos, amos y criados, expresan sus apetitos carnales; no faltan los chistes más o menos escabrosos sobre el sexo y las relaciones eróticas.

En apariencia, pareciera que Rojas ha subvertido o sobrepasado los estrechos límites de lo prohibido en todo lo relacionado con el amor erótico. Pero la verdad del caso, o la realidad, es bien distinta, porque las cosas acaban volviendo a su cauce, es decir, al reducido lugar que imponen las convenciones morales de la época. La que podemos llamar «justicia poética» termina imponiéndose de tal forma que las fronteras de lo prohibido se alzan de nuevo como límites infranqueables, de modo que el violador suele terminar pagando con su vida su ignominioso delito; la mujer ardiente que ha expresado, y tal vez conseguido, su deseo carnal acaba siendo castigada por su liviandad y osadía; tal vez lo único que termina siendo lo que aparenta sea el mundo bajo de la servidumbre y la galería de tipos que viven prácticamente al margen de la moral y las buenas costumbres; es decir, la especie de fauna humana que aparece en los barrios populares de Madrid, y que habla y actúa con la libertad propia de lo marginal y carnavalesco. Lo demás es tan solo apariencia, o sea, que, como diría el gran poeta, «hay siempre un ascua de veras / en su incendio de teatro». ${ }^{84}$

\footnotetext{
${ }^{83}$ Véase sobre el tema los trabajos de R. MacCurdy, «The bathing nude in Golden Age drama», Romance Notes, v. 2 (1959), pp. 36-39, y «Women and sexual love in the plays of Rojas Zorrilla: tradition and innovation», Hispania, 62 (May-September 1979), pp. 255-265.

${ }^{84}$ En este sentido, se había expresado M. G. Profeti: «Como la comedia es propuesta como modelo de conducta caballeresca, no solo desaparece la acción baja o vulgar, sino que la palabra misma será a un tiempo el vehículo de erotismo y su negación. No se puede poner en escena a un galán abrazando o besando a una dama, o a una dama desnudándose; sino que tan sólo se podrá contar que se ha entrevisto el pie desnudo de la amada, o a la amada bañándose». Y añade: «En el teatro barroco, pues, la escena erótica más auténtica y profunda es la que no existe, la que se sitúa más allá, la que la palabra evoca por negarla»; «La escena erótica de los siglos áureos», op. cit., pp. 73-74.
} 
Los excesos atribuidos a Rojas Zorrilla, al menos en este aspecto, son, pues, tan solo aparentes: en tanto que lleva a las tablas planteamientos de encuentros amatorios, voluntarios o forzados, desnudos femeninos, el dramaturgo parece atrevido, sobre todo por la frecuencia y reiteración con que lo hace. Pero su atrevimiento se desvanece en cuanto siempre termina sometiéndose, como era lógico, a los rígidos códigos del decoro teatral (no olvidemos que, de otro modo, sencillamente sus comedias no se hubieran podido representar).$^{85}$

${ }^{85}$ Así, como decía Profeti, el hecho de que se frustre de algún modo la relación erótica (la consentida o la forzada) tiene que ver obviamente con el moralismo que «esclerotiza las formas teatrales, y privilegia el 'decir' respecto al 'mostrar'» (ibidem, p. 76). El contacto erótico no se ve en las tablas: se alude, se cuenta, se imagina, se goza a través de su representación simbólica. 